Study Abroad/Reflection Paper

ISSN: 2162-3104 Print/ ISSN: 2166-3750 Online

Volume 5, Issue 2 (2015), pp. 201-203

(C) Journal of International Students

http://jistudents.org/

\title{
Improving Intercultural Education at Chinese Institutions from German Experience
}

\author{
Lihe Huang \\ Tongji University (China)
}

While flying on an airplane to Germany, heading to my new appointment as a visiting scholar, I reminded myself that there would likely be some cultural differences upon embarking on this new journey. But after I began my sojourn there, I still found myself surprised by the cultural shock I was experiencing. I had taken for granted that my English education and some reading on German culture and society could provide me adequate knowledge to get along with these "Westerners".

Germans are unique, as they describe themselves, and interaction in everyday routine as well as in a professional setting gradually allowed me to learn about the characteristics of this country's culture and its people's lifestyle and mentality. To be very serious and forthright is one of the qualities in Germans which left me with a profound impression. As an example, one interesting experience occurred during an academic presentation I delivered. Upon completing my talk, I expected some routine or polite appreciation for my well-prepared presentation, but my German audience immediately focused on asking questions of a critical nature after my talk. "In many aspects, we are even much more straightforward than Americans," I was told by my German colleagues. After a series of similar experiences, I gradually came to believe that these attitudes of critical inquiry, curiosity and earnestness embedded in their culture and national spirit help promote Germans to progress in science and technology. They are modest and unpretentious in the way they seek to improve their products and service, and meanwhile, they are also very proud of their country, as exemplified in a famous German song "Deutschland" originally by the band "Die Prinzen": Wir können stolz auf Deutschland (We can be proud of Germany).

Through the well-designed introductory seminar and study tour arranged by Alexander von Humboldt Foundation, which provided the grant for my research on foreign languages teaching and intercultural education in Germany, I familiarized myself with many facts related to the social, economic, political, cultural and historical situation in Germany. I sought to enrich myself with deeper exposure to my new intercultural settings by making efforts to venture out and explore the country and other European countries to gain a better understanding of the cultures. These experiences informed me how the country created numerous masterpieces in science and arts, how its people committed themselves to face the challenges in the process of development, and how the country connected itself to the international arena in a global capacity. Indeed, there were many interesting events and valuable opportunities to learn about Germany and Europe, among which a key highlight included a reception from German President Joachim Gauck and a meeting with German Chancellor Angela Merkel. 
Additionally, the interaction and friendship with other fellows from China, America and Russia offered great opportunities to practice real intercultural communication, to learn to respect and admire different cultures and to consider world events from various perspectives in the international arena. The intercultural interaction with Germans and people from other parts of the world also taught me much about diversity and beauty in life, which largely expanded my insight. Meanwhile, it was an excellent opportunity to express China's philosophies and ideas in an internationally-understandable way and learn about others. Through these experiences, I gained a profound understanding of how significant and important it is to promote intercultural communication and friendship among younger generations from different cultures, beliefs and religions for the sake of a better and more harmonious world in the future.

To me, Germany is a true "Land of Ideas" and has contributed greatly to my academic achievement. Numerous activities, events, exhibitions, workshops or even daily encounters I experienced inspire me to develop more creative ideas in my own research. Thanks to the support by the German Chancellor Fellowship (Bundeskanzler-Stipendium) from Alexander von Humboldt Foundation, I learned much during my year appointment about how German higher education integrates itself into the process of internationalization while keeping its own traditions. Today, great emphasis on intercultural education is advocated at Chinese universities as the importance of cultivating greater numbers of globally-aware individuals has become a priority. The establishment of the global vision and the improvement of intercultural communication skills demand students to acquire basic intercultural knowledge, global awareness, attitudes to respect multiculturalism, and common values in different cultures. Germany's approach to the internationalization of higher education helps students to function competitively around the world, and better understanding the German approach has framed my research, in which I examine how China can benefit from understanding the German experience.

I have investigated both University of Cologne and University of Bremen with regard to improving students' intercultural competence, and also made a comparison between them and my home university in China regarding international strategy and policy; service for international students; intercultural competence training; building of campus diversity; and intercultural activities organization. Both German universities offer help, training and consultation for international students in order to help them adapt to learning and living in Germany. Various intercultural activities are well organized. In particular, the training and certification of intercultural competence at Bremen University is quite well-developed and very inspiring.

My study argues that intercultural education should be considered important for student outcomes of institutional internationalization, and a co-curricular activity-based intercultural competence training program can improve students' global-mindedness and intercultural competence. There are two concepts which need to be explained here: First, what is an intercultural activity? Since intercultural competence is gradually developed from one's social interaction rather than mere knowledge accumulation, intercultural education should be more activity-based instead of pure traditional indoor classroom teaching. The scope of "activity" in my study is quite broad, which includes any interaction related to intercultural or international communication. Both indoor activities (e.g. lectures, workshops and training courses, etc.) and outdoor activities (e.g. group studies or visits, projects in college grounds or the local community, etc.) are involved. Second, why should the program be "co-curricular"? Cocurriculum in the study implies that the academic coursework is related to the out-of-class activities in terms of intercultural education. This is a reflection of UNESCO's belief that "Intercultural education cannot be just a simple 'add-on' to the regular curriculum. It needs to 
concern the learning environment as a whole, as well as other dimensions of educational processes..." (UNESCO, 2006, p. 19). Furthermore, my study advocates that activities in the training program should be organized using English as a lingua franca. In Chinese higher education institutions, College English is a compulsory course for all non-English majors. I agree on the idea that English education should help meet the needs of the internationalization of Chinese higher education, the cultivation of international talents, and the new national development strategies of opening China further to the outside world (Shu, 2013). Both indoor College English teaching and an activity-based training program then constitute a bi-faceted and relatively complete scheme for intercultural competence development, which seems to be pragmatic and effective in Chinese institutions. Certainly, developing intercultural competence with English as a lingua franca does not mean to limit the program's content to the cultures in English-speaking countries, or to develop specific communicative rules of the target language, but aims to foster students' appropriate strategies to communicate with people from diverse languages and cultural backgrounds taking English as a tool.

The close exchange between China and Germany provides even more opportunities for people to make good use of their profession and strengths to contribute to the tightening partnership between the two countries. My experience in Germany not only provided me a chance to improve professional skills and develop new insights, but also me to relay helpful

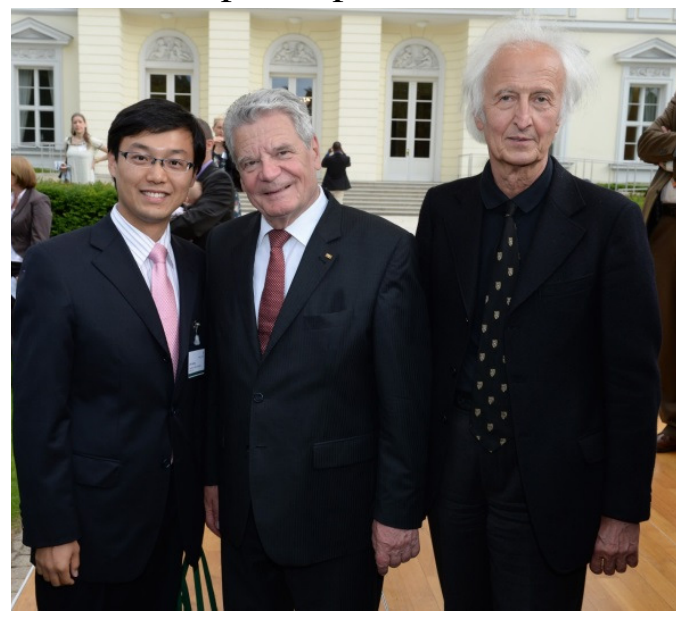
information to my home institution in China. Tongji University has a long tradition in developing close ties with Germany, and this experience helps me continue to foster ties and engage in this tradition as a rising faculty. Beyond all of these opportunities I had in Germany, I am very grateful for the help and support from my cooperative supervisors, Prof. Dr. Yasemin Karakaşoğlu and Dr. Susanne Preuschoff, both in the field of intercultural education, and the staff from Alexander von Humboldt Foundation. All that I have experienced and the friendship with the other research fellows and friends in Germany will be unforgettable and everlasting in my mind.

Photo: Lihe Huang with German President Joachim Gauck and Prof. Dr. Helmut Schwarz, President of Humboldt Foundation at a reception in the official residence of the President of Germany.

\section{REFERENCES}

Shu, D. (2013). Reorienting college English to serve national development strategies and cultivate talents with international visions. Foreign Language Research, 175 (6), 90-96.

UNESCO. (2006). UNESCO Guidelines on Intercultural Education. Paris, France:

United Nations Educational Scientific and Cultural Organization.

LIHE HUANG is a Humboldt Fellow of Germany-based Alexander von Humboldt Foundation, conducting research at University of Cologne and University of Bremen. Mr. Huang is also a member of several academic associations both internationally and in China. He has published over 30 peer-reviewed papers, and undertaken several research projects granted by different institutions at various levels. E-mail: cranehlh@ @otmail.com 